\title{
PENGARUH JENIS AGREGAT RINGAN BUATAN TERHADAP KUAT TEKAN BETON RINGAN \\ EFFECT OF ARTIFICIAL LIGHTWEIGHT AGGREGATE TYPE FOR COMPRESSIVE STRENGTH OF LIGHTWEIGHT CONCRETE
}

\author{
Nurul Aini Sulistyowati ${ }^{\text {a) }}$, Deden Suripto ${ }^{\text {b) }}$ \\ ${ }^{a}$ Puslitbang Permukiman Balitbang PU \\ Jalan Panyawungan, Cileunyi Wetan, Kabupaten Bandung \\ ${ }^{b)}$ Balai Besar Teknologi Kekuatan Struktur - BPPT \\ Kawasan PUSPIPTEK Gd. 220 Serpong, Tangerang 15314 \\ e-mail : nurulaini657@yahoo.co.id, deden_suripto@yahoo.co.id
}

Tanggal masuk naskah : 01/03/2013; Tanggal revisi : 01/04/2013; Tanggal persetujuan cetak : 08/04/2013

\begin{abstract}
Abstrak
Penelitian bertujuan untuk mengetahui sifat fisis dan mekanis agregat ringan serta kuat tekan beton yang menggunakan agregat ringan. Pembuatan agregat ringan menggunakan komposisi campuran shale + serbuk gergaji kayu, shale + abu sekam padi, shale + sekam padi, serta shale. Pembuatan beton ringan struktural menggunakan rancangan campuran dengan kuat tekan rencana sebesar $25 \mathrm{MPa}$. Benda uji berbentuk silinder dengan diameter $10 \mathrm{~cm}$ dan tinggi $20 \mathrm{~cm}$. Pengujian kuat tekan beton dilakukan pada umur 14 hari, 21 hari dan 28 hari. Berat jenis agregat ringan kurang dari 1,5 dengan penyerapan air terbaik pada agregat ringan shale dan kekerasan terbaik pada agregat ringan shale + abu sekam padi. Kuat tekan beton agregat ringan shale + serbuk gergaji sebesar 265,04 kg/ $\mathrm{cm}^{2}$ dan agregat ringan shale + abu sekam padi $264,73 \mathrm{~kg} / \mathrm{cm}^{2}$ lebih tinggi dari kuat tekan rencana. Kuat tekan beton agregat ringan shale + sekam padi sebesar 234,82 $\mathrm{kg} / \mathrm{cm}^{2}$ dan agregat ringan shale sebesar $212,23 \mathrm{~kg} / \mathrm{cm}^{2}$ lebih rendah dari kuat tekan rencana.
\end{abstract}

Kata kunci : agregat ringan buatan,beton ringan, shale, serbuk gergaji kayu, sekam padi, abu sekam padi

\begin{abstract}
The aim of the research was to know the mechanical and physical properties of lightweight aggregate and compressive strength of concrete with lightweight aggregate. The raw materials for manufacturing lightweight aggregate include the mix composition of shale + sawdust, shale + rice husk, shale + rice husk ash, and shale. Th structural lightweight concrete was designed to have a compressive strength of $25 \mathrm{MPa}$. The specimen was cylindrical of 10 diameter and $20 \mathrm{~cm}$ high. The compressive strength of concrete tested at ages of 14 days, 21 days, and 28 days. Specific gravity of lightweight aggregate was less than 1.5, the best water absorption was of the lightweight aggregate shale and the best hardness that of the lightweight aggregate shale+ rice husk ash. The compressive strength of concrete with lightweight aggregate shale + sawdust $265.04 \mathrm{~kg} / \mathrm{cm}^{2}$ and shale + rice husk ash $264.73 \mathrm{~kg} / \mathrm{cm}^{2}$, all of which were higher than compressive strength. The compressive strength of concrete with lightweight aggregate shale + rice was husk $234.82 \mathrm{~kg} / \mathrm{cm}^{2}$ and that of the shale was 212.23 $\mathrm{kg} / \mathrm{cm}^{2}$, which were lower than the designed compressive strength.
\end{abstract}

Keywords : artificial lightweight aggregate, lightweight concrete, shale, sawdust, rice husk, rice husk ash 


\section{PENDAHULUAN}

Bangunan bertingkat yang dibangun oleh pengembangan pada umumnya lebih dari (5) lima lantai dan digunakan untuk apartement. Bangunan tersebut memerlukan konstruksi yang baik agar sesuai dengan umur rencana. Untuk mengurangi beban mati bangunan tersebut, dapat dilakukan dengan menggunakan bahan bangunan yang ringan antara lain beton ringan.

Beton ringan merupakan beton yang mempunyai berat kurang dari $1.800 \mathrm{~kg} / \mathrm{m}^{3}$. Beton ringan diperoleh dengan cara menambah jumlah pori-pori udara kedalam campuran beton. Pembuatan beton ringan dapat dilakukan dengan cara sebagai berikut $^{(1):}$

- membuat gelembung-gelembung gas atau udara dalam adukan semen sehingga akan terjadi banyak poripori udara didalam beton;

- menggunakan agregat ringan, misalnya batu apung yang mengakibatkan beton menjadi lebih ringan daripada beton normal;

- membuat beton tidak dengan butirbutir agregat halus (beton non pasir), hanya dibuat dari semen dan agregat kasar (dengan butir maksimum agregat kasar sebesar $20 \mathrm{~mm}$ atau 10 $\mathrm{mm}$ ).

Pembuatan gelembung gas atau udara dalam adukan semen dilakukan dengan menggunakan foaming agent seperti aluminium. Penambahan foamimg agent yang terlalu banyak akan memberikan kecenderungan memperbanyak pori yang dihasilkan dalam campuran dan akan menurunkan kuat tekan pasta. Penambahan serat alam akan menambah kuat tekan mortar, namun penggunaan serat alam yang terlalu banyak akan menurunkan kuat tekan ${ }^{(2)}$.

Bata beton pejal non pasir dengan bahan pecahan genteng (batanes) dengan komposisi campuran semen (pc) : pecahan genteng sebesar 1:6 dan 1:7 termasuk dalam mutu II dengan kuat tekan $6,5 \mathrm{~kg} / \mathrm{cm}^{2}$ serta komposisi campuran 1: 8 sampai dengan 1:12 termasuk mutu III dengan kuat tekan 3,5 $\mathrm{kg} / \mathrm{cm}^{2(3)}$. Kuat tekan beton yang menggunakan agregat kasar buatan dari batu kapur yang mengembang (expanded shale materials) sebesar 29,35 $\mathrm{MPa}^{(4)}$. Penambahan fraksi agregat kasar breksi batu apung menyebabkan berkurangnya berat jenis dan kuat tekan beton yang dihasilkan.
Beton ringan struktural dapat dicapai pada penggunaan fraksi agregat breksi batu apung sebesar $65 \%$ dari total volume agregat yang digunakan ${ }^{(5)}$.Variasi proporsi campuran, variasi penambahan superplasticizer dan interaksinya memberikan pengaruh yang nyata terhadap nilai kuat tekan beton ringan ${ }^{(6)}$. Agregat ringan dapat dibedakan menjadi agregat ringan alami dan agregat ringan buatan. Agregat ringan alami seperti agregat breksi batu apung, skoria atau tufa. Agregat ringan buatan dibuat dengan membekahkan melalui proses pemanasan bahan seperti terak dari peleburan besi, tanah liat, diatome, abu terbang, batu sabak, batu serpih, batu lempung, perlit dan vermikulit. Di Indonesia bahan baku yang digunakan untuk pembuatan agregat ringan adalah shale. Proses pembuatan agregat ringan tersebut menghasilkan limbah yang berupa shale dalam bentuk butiran halus akibat adanya pemecahan bongkahan shale. Limbah tersebut belum dimanfaatkan.

Serbuk gergaji kayu dapat digunakan sebagai media tanam. Pemanfaatan limbah tersebut belum optimal dan masih banyak yang hanya dibakar begitu saja. Sebagian industri bata menggunakan bahan campuran sekam padi maupun abu sekam padi untuk memperbaiki sifat bata yang diproduksi. Berasumsi dari hal tersebut akan dilakukan pemanfaatan serbuk gergaji kayu, sekam padi, maupun abu sekam padi sebagai bahan campuran limbah shale dalam pembuatan agregat ringan.

Tujuan penelitian untuk mengetahui sifat fisis dan mekanis agregat ringan buatan serta kuat tekan beton ringan yang menggunakan agregat ringan tersebut.

\section{BAHAN DAN METODA}

Penelitian ini dilakukan 2 (dua) tahap yang terdiri dari pembuatan agregat ringan dan pembuatan beton yang menggunakan agregat ringan sebagai agregat kasar. Pembuatan agregat ringan menggunakan 4 (empat) komposisi campuran bahan baku meliputi shale murni, (1 bagian shale +1 bagian serbuk gergaji kayu), (1bagian shale + 1 abu sekam padi), dan (1 bagian shale +1 bagian sekam padi). Shale yang digunakan dalam bentuk butiran halus yang diperoleh dari hasil ikutan pemecahan bongkahan shale. Pembuatan agregat ringan dimulai dengan pencampuran bahan baku hingga homogen dan dilanjutkan pembuatan butiran 
(pelet) agregat dengan mesin peletizer. Pembuatan pelet dengan cara memberi air pada campuran bahan baku. Butiran (pelet) agregat dikeringkan secara alami selama 14 hari. Pembakaran pelet dilakukan pada mesin tungku putar dengan suhu $1000^{\circ} \mathrm{C}$. Pengujian sifat fisis dan mekanis agregat kasar meliputi berat jenis, penyerapan air, analisis ayak, bobot isi gembur dan bobot isi padat, serta kekerasan butir agregat. Semua pengujian tersebut menggunakan rujukan standar SNI, kecuali untuk kekerasan BS-812-1975.

Pembuatan beton menggunakan rancangan campuran dengan kuat tekan rencana sebesar $25 \mathrm{MPa}$. Bahan yang digunakan meliputi pasir, agregat ringan (agregat kasar), semen portland komposit dan air. Pengujian pasir terdiri dari berat jenis, penyerapan air, kadar air, berat jenis, bobot isi gembur dan bobot isi padat, kadar lumpur dan analisis ayak. Rujukan standar yang digunakan untuk pengujian adalah SNI. Beton yang dibuat berbentuk silinder dengan diameter $10 \mathrm{~cm}$ dan tinggi $20 \mathrm{~cm}$. Pengujian kuat tekan beton dilakukan pada berumur 14 hari, 21 hari, dan 28 hari. Pembuatan beton menggunakan rujukan standar SNI 03-34492002 mengenai Tatacara Perancangan Campuran Beton Ringan dengan Agregat Ringan. Kebutuhan bahan baku untuk pembuatan beton sebagai berikut:

Tabel 1. Kebutuhan Bahan Baku

\begin{tabular}{lcccc}
\hline & $\begin{array}{c}\text { Semen } \\
(\mathrm{kg})\end{array}$ & $\begin{array}{c}\text { Air } \\
(\mathrm{kg})\end{array}$ & $\begin{array}{c}\text { Kasar } \\
(\mathrm{kg})\end{array}$ & $\begin{array}{c}\text { Halus } \\
(\mathrm{kg})\end{array}$ \\
\hline $\begin{array}{l}\text { Tiap 1 } \mathrm{m}^{3} \\
\text { (agregat }\end{array}$ & 375 & 81 & 550 & 750 \\
$\begin{array}{l}\text { kasar } \\
\text { kering } \\
\text { permukaan) }\end{array}$ & & & & \\
\hline
\end{tabular}

Pengaruh penggunaan jenis agregat ringan buatan kuat tekan beton diketahui dengan membuat analisis ragam. Untuk mengetahui adanya perbedaan nilai antar kuat tekan diuji lanjut dengan uji pembandingan ganda prosedur Tukey $\mathrm{W}^{(7)}$

\section{HASIL DAN PEMBAHASAN}

Hasil pengujian analisis ayak untuk setiap jenis agregat ringan dengan nilai modulus halus butir pada gambar berikut:

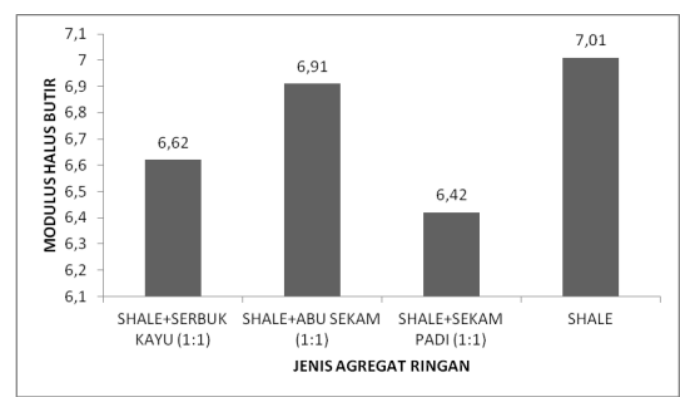

Gambar 1 : Hubungan Jenis Agregat Ringan dengan Modulus Halus Butir

Modulus kehalusan butir yang paling kasar adalah agregat ringan shale dengan nilai 7,01. Sementara agregat ringan campuran shale yang terkasar adalah agregat ringan shale + abu sekam padi dengan modulus halus butir sebesar 6,91. Besaran modulus halus butir untuk semua agregat ringan buatan memenuhi persyaratan SNI 036861.1-2002 yang menentukan modulus halus butir agregat kasar sebesar 6,00 7,10.

Agregat ringan yang dibuat mempunyai berat jenis kurang dari 1,5. Agregat ringan shale +abu sekam padi mempunyai berat jenis tertinggi yaitu sebesar 1,42 dan yang terendah agregat ringan shale + sekam padi sebesar 1,19 serta agregat ringan shale sebesar 1,2. Pencampuran serbuk gergaji kayu dan abu sekam padi pada shale mengakibatkan bertambahnya berat jenis agregat ringan. Berat jenis agregat ringan telah memenuhi spesifikasi agregat ringan untuk beton ringan struktur SNI 03-2461-2002 yang menentukan sebesar 1,0 1,8. Secara lengkap hasil pengujian berat jenis dapat dilihat pada gambar berikut:

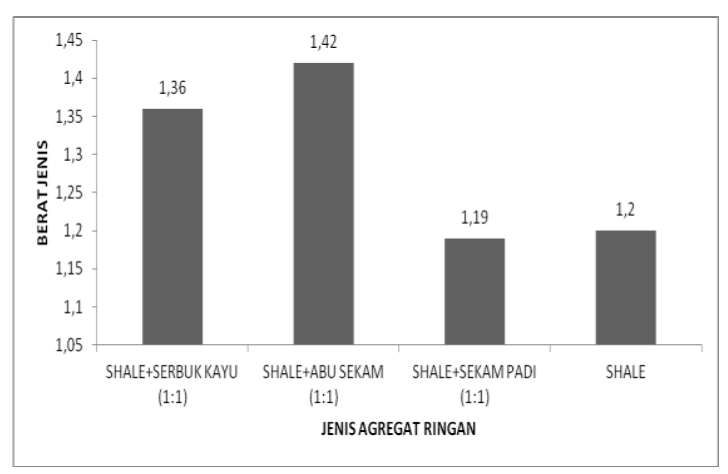

Gambar 2 : Hubungan Jenis Agregat Ringan dengan Berat Jenis 
Bobot isi gembur dan bobot isi padat memperlihatkan bahwa bobot isi yang tertinggi pada agregat ringan shale + serbuk gergaji kayu. Besaran bobot isi gembur tersebut sebesar 0,82 dan bobot isi padat sebesar 0,9. Agregat ringan shale mempunyai bobot isi yang terendah dengan bobot isi gembur 0,52 dan bobot isi padat 0,53 .

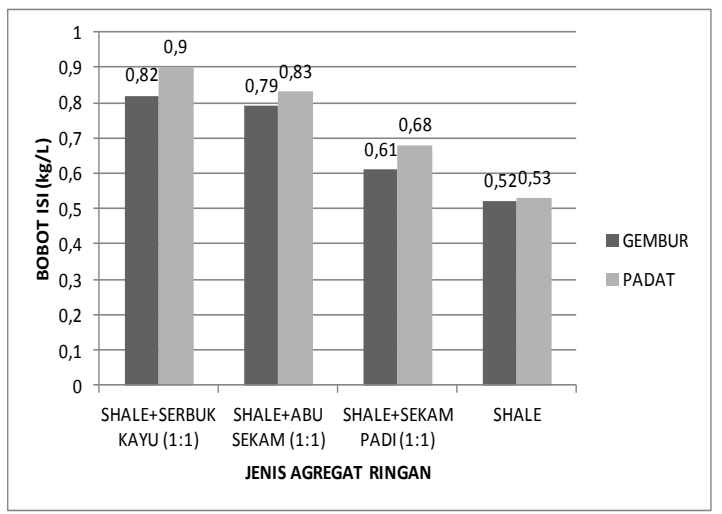

Gambar 3 : Hubungan Jenis Agregat Ringan dengan Bobot Isi

Hasil pengujian penyerapan air agregat ringan dapat dilihat pada gambar berikut:

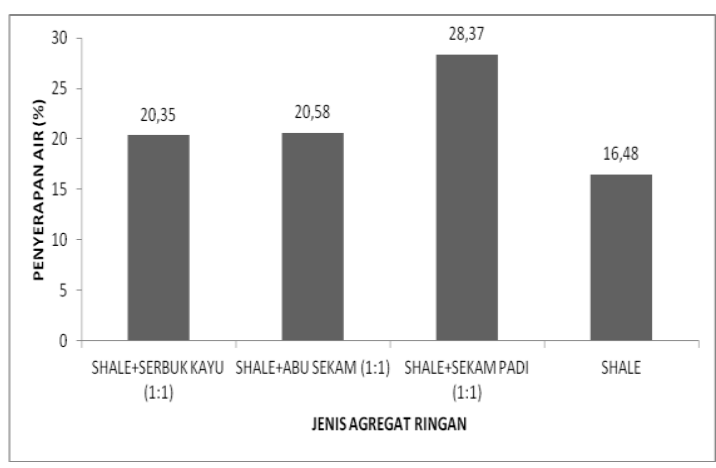

Gambar 4 : Hubungan Jenis Agregat Ringan dengan Penyerapan Air

Agregat ringan shale + sekam padi mempunyai penyerapan air yang tertinggi dengan nilai $28,37 \%$. Penyerapan air yang terendah dicapai oleh agregat ringan shale sebesar 16,48 \%. Penambahan serbuk gergaji kayu, abu sekam padi, maupun sekam padi pada shale mengakibatkan bertambahnya penyerapan air agregat ringan. Bahan-bahan tersebut dalam pelet agregat setelah dibakar pada suhu tinggi menjadikan agregat semakin porus karena ikut terbakar dan membentuk rongga-rongga pada agregat terutama sekam padi. Dengan semakin porusnya agregat ringan membuat penyerapan airnya semakin bertambah. Penyerapan air yang memenuhi spesifikasi agregat ringan berdasarkan ${ }^{(6)}$ SNI 03-24612002 hanya agregat ringan shale karena nilainya kurang sebesar $20 \%$.

Kekerasan agregat yang terendah adalah agregat ringan shale + serbuk gergaji kayu dengan nilai 80,6 \%. Agregat ringan shale + abu sekam padi mempunyai kekerasan yang paling baik dengan nilai $46,96 \%$. Penambahan abu sekam padi pada shale menyebabkan bertambahnya kekerasan agregat ringan. Hal ini diduga karena adanya kandungan silika pada abu sekam padi yang mengakibatkan pelet agregat menjadi semakin keras setelah dibakar pada suhu tinggi. Penambahan serbuk gergaji kayu dan sekam padi pada shale mengakibatkan berkurangnya kekerasan agregat ringan buatan. Hal ini karena hilangnya serbuk gergaji kayu dan sekam padi pada saat pembakaran agregat, sehingga mengakibatkan agregat tersebut mempunyai banyak rongga atau kurang padat. Kondisi ini yang membuat berkurangnya kekerasan agregat ringan. Hasil uji kekerasan agregat pada gambar berikut:

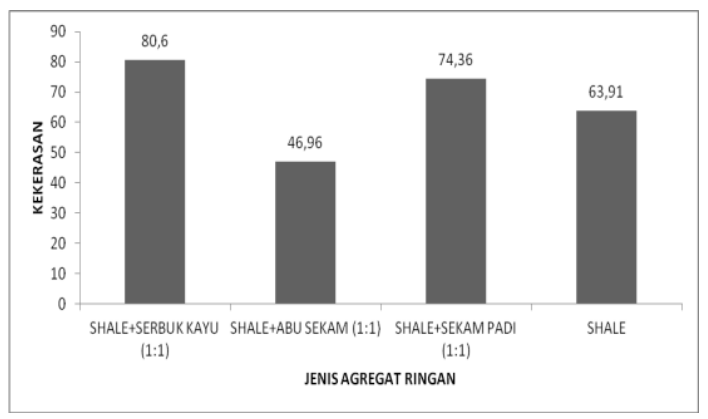

Gambar 5 : Hubungan Jenis Agregat Ringan dengan Kekerasan

Kemampuan pasir untuk menyerap air sebesar 5,26 \%. Hal ini menggambarkan bahwa pasir mempunyai butiran-butiran yang mampu untuk menyerap air. Kadar air pasir sebesar 3,09 \%, besaran tersebut menunjukkan bahwa pasir cukup kering. Hal ini terjadi karena pasir disimpan di bawah atap, sehingga terhindar dari air hujan. Pasir yang digunakan mempunyai berat jenis sebesar 2,48. Pasir termasuk pasir normal dengan berat jenis 1,9 3,1. Bobot isi gembur sebesar $1,45 \mathrm{~kg} / \mathrm{L}$ dan bobot isi padat $1,69 \mathrm{~kg} / \mathrm{L}$. Kadar lumpur pasir sebesar 4,2\% dibawah persyaratan kadar lumpur untuk 
agregat halus dalam pembuatan beton harus kurang dari $5 \%$. Modulus kehalusan pasir sebesar 2,54, pasir telah memenuhi persyaratan SNI 03-6861.1-2002 yang menentukan modulus kehalusan untuk agregat halus sebesar 1,5 3,8. Berdasarkan hasil analisis ayak, pasir yang digunakan termasuk zone 2.

Hasil pengujian kuat tekan disajikan pada gambar berikut:

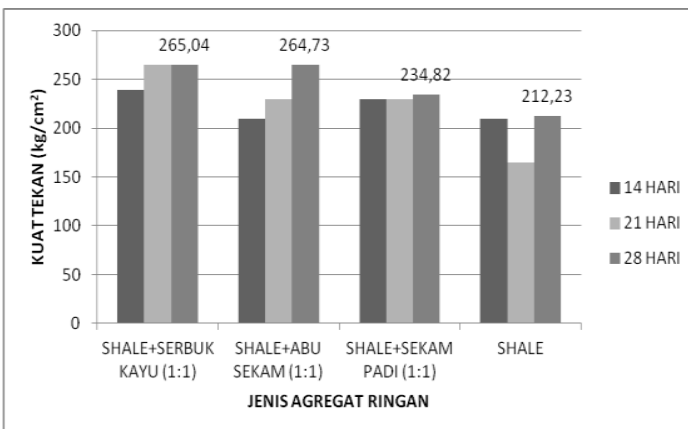

Gambar 6 : Hubungan Jenis Agregat Ringan Dengan Kuat Tekan Beton Ringan

Kuat tekan beton memperlihatkan bahwa kuat tekan beton meningkat dengan bertambahnya umur pengujian hingga 28 hari. Hal ini sesuai dengan kaidah bahwa pengerasan dan pengikatan semen terjadi secara sempurna pada umur 28 hari. Kuat tekan beton tertinggi diperoleh pada agregat ringan shale + serbuk gergaji kayu sebesar $265,04 \mathrm{~kg} / \mathrm{cm}^{2}$ dan terendah agregat ringan shale sebesar $212,23 \mathrm{~kg} / \mathrm{cm}^{2}$. Selain itu penambahan serbuk gergaji, abu sekam dan sekam padi pada shale untuk pembuatan agregat ringan dapat meningkatkan kuat tekan beton yang menggunakan agregat kasar tersebut. Hal ini sesuai dengan analisis ragam (Tabel 2) bahwa jenis agregat ringan berpengaruh nyata terhadap kuat tekan beton. Kuat tekan beton ditentukan oleh jenis agregat ringan (agregat kasar) yang digunakan karena dalam pembuatan beton menggunakan pasir, semen, air dan rancangan campuran yang sama. Kuat tekan beton yang menggunakan agregat ringan shale + serbuk gergaji kayu sebesar 265,04 $\mathrm{kg} / \mathrm{cm}^{2}$ dan agregat ringan shale $+\mathrm{abu}$ sekam sebesar $264,73 \mathrm{~kg} / \mathrm{cm}^{2}$ lebih tinggi dari kuat tekan beton rencana 25 MPA (250 $\mathrm{kg} / \mathrm{cm}^{2}$ ). Kuat tekan beton yang menggunakan agregat ringan shale + sekam padi sebesar $234,82 \mathrm{~kg} / \mathrm{cm}^{2}$ dan agregat ringan shale sebesar $212,23 \mathrm{~kg} / \mathrm{cm}^{2}$ lebih rendah dari kuat tekan beton rencana.

Tabel 2. Analisis Ragam Beton Ringan

\begin{tabular}{cccc}
\hline No. & \multicolumn{1}{c}{ Sifat } & Fhitung & F tabel \\
\hline 1. & Kuat tekan & $5,769^{*}$ & 3,49 \\
\cline { 1 - 2 } 2. & Kadar air & 1,902 & $(0,05)$ \\
& & & 5,95 \\
& & & $(0,01)$ \\
\hline
\end{tabular}

Keterangan: * = berpengaruh nyata

Hasil uji beda (Tabel 3) menunjukkan bahwa hanya kuat tekan beton yang menggunakan agregat ringan shale + serbuk gergaji kayu dan kuat tekan beton yang menggunakan agregat ringan shale + abu sekam yang berbeda nyata dengan kuat tekan beton agregat shale. Kuat tekan beton yang menggunakan agregat ringan shale + sekam padi sama dengan kuat tekan beton yang menggunakan agregat ringan shale. Kuat tekan beton agregat ringan shale lebih kecil dari hasil penelitian ${ }^{(4)}$, walaupun agregat ringannya menggunakan bahan baku yang sama yaitu shale. Hal ini terjadi rancangan campuran beton yang digunakan berbeda dan bentuk agregat ringan. Bentuk agregat ringan yang digunakan dalam penelitian ini relatif lebih bulat, karena dibuat pelet terlebih dahulu sebelum dibakar. Sampel silinder beton ringan setelah dilakukan pengujian kuat tekan seperti pada Gambar 7.

Tabel 3. Hasil Uji Beda

\begin{tabular}{lcc}
\multicolumn{1}{c}{ Kuat Tekan Beton } & $\begin{array}{c}\text { Nilai } \\
\text { beda }\end{array}$ & $\begin{array}{c}\text { Nilai Tukey } \\
\text { w }\end{array}$ \\
\hline Agregat shale + & $52,82^{*}$ & 44,765 \\
serbuk kayu dengan & & $(0,05)$ \\
agregat shale & & 58,621 \\
& & $(0,01)$ \\
\hline Agregat shale + abu & $52,50^{*}$ & Cek tukey \\
sekam padi dengan & & \\
agregat shale & & \\
\hline
\end{tabular}

Keterangan: * = berbeda nyata

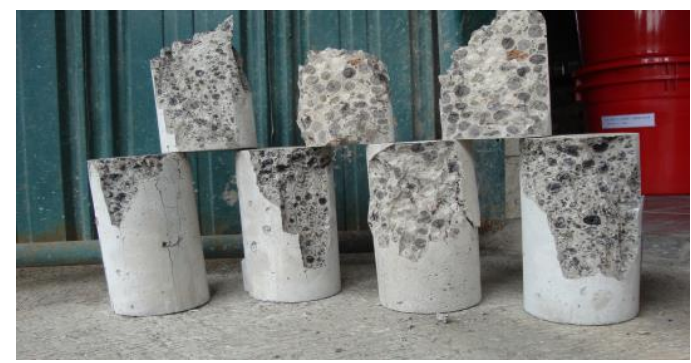

Gambar 7 : Sampel Beton Ringan Bekas Pengujian Kuat Tekan 


\section{KESIMPULAN}

Kesimpulannya agregat ringan yang dibuat mempunyai berat jenis kurang dari 1,5 dan memenuhi persyaratan SNI 03-24612002; agregat ringan shale mempunyai penyerapan air yang terendah dan memenuhi persyaratan SNI 03-2461-2002; agregat ringan dari shale + abu sekam padi mempunyai kekerasan butir yang terbaik $46,96 \%$; kuat tekan beton ringan yang menggunakan agregat ringan shale + serbuk gergaji $265,04 \mathrm{~kg} / \mathrm{cm}^{2}$ dan agregat ringan shale + abu sekam padi $264,73 \mathrm{~kg} / \mathrm{cm}^{2}$ lebih tinggi dari kuat tekan beton rencana; sedangkan kuat tekan beton ringan yang menggunakan agregat ringan shale + sekam padi sebesar $234,82 \mathrm{~kg} / \mathrm{cm}^{2}$ dan agregat ringan shale sebesar $212,23 \mathrm{~kg} / \mathrm{cm}^{2}$ lebih rendah dari kuat tekan beton rencana.

Penulis sarankan agar pembuatan butiran agregat ringan sebaiknya dicoba yang tidak berbentuk bulat.

\section{DAFTAR PUSTAKA}

1. Tjokrodimuljo, K., "Teknologi Beton", Universitas Gadjah Mada, Yogyakarta, 2009.

2. Manfaluty, L., dkk. "Beton Ringan Berserat dengan Memanfaatkan Lumpur Bakar Sidoarjo dan Serat Alam”, digilib.its.ac.id/.../ITS-paper25201-3110105022-pap. (Diunduh 27 Juni 2013)

3. Endroyo, B., "Karakteristik Bata Beton Non Pasir dengan Agregat Pecahan Genteng", Dinamika Teknik Sipil Vol. 10, No.1, Januari 2010, Publikasiilmiah.ums.ac.id/.../(10)_Bam bang\%20Endro. (Diunduh 13 Juni 20013).

4. Tjaronge, M.W, "Studi Dasar Mengenai Beton yang Menggunakan Agregat Butan yang Ringan Sebagai Agregat Kasar". Media Komunika Teknik Sipil Volume 13, No. 1, Edisi XXXI Pebruari 2009.
5. Santosa, A dan Slamet W, "Optimasi Sifat Mekanik Beton Ringan dengan Agregat Breksi Batu Apung dengan Bahan Tambah Mineral dan Serat Campuran",2013,

Staff.uny.ac.id/.../Jurnal\%20INERSIA\% 20BETON. (Diunduh 13 Juni 2013).

6. Suseno, H. dkk, "Pengaruh Variasi Proporsi Campuran dan Penambahan Superplasticizer terhadap Slump, Berat Isi dan Kuat Tekan Beton Ringan Struktural Berat gregat Batuan Andesit Piroksen". Jurnal Rekayasa Sipil Vol.2, No.3, 2008, (Diunduh 13 Juni 2013).

7. Steel, R.G.D dan James H. Torrie, "Prinsip dan Prosedur Statistika", Gramedia Pustaka Utama, Jakarta, 1993.

8. Badan Standar Nasional, 2000, "Kuat Tekan Beton". SNI 15-20942000.

9. Badan Standar Nasional, 2002, "Spesifikasi Agregat Ringan untuk Beton Ringan Struktur". SNI 032461-2002.

10. Badan Standar Nasional, 2002, "Tata Cara Perancangan Campuran Beton Ringan dengan Agregat Ringan”. SNI 03-3449-2002.

11. Badan Standar Nasional, 2002, "Spesifikasi Bahan Bangunan Bukan Logam”. SNI 03-6861.1-2002.

12. Loka Perintisan Bahan Bangunan Cilacap, Brosur "ALWA (Artificial Light Weight Aggregate"). 